\title{
LAND, PROPERTY AND USER'S RIGHTS ACCORDING TO ISLAMIC-OTTOMAN REFORMS IN IRAQ
}

\author{
L. AL-OSSMI ${ }^{1,2}$ \& V. AHMED ${ }^{2}$ \\ ${ }^{1}$ College of Architecture, Thi-Qar University, Iraq. \\ ${ }^{2} \mathrm{School}$ of Built Environment, Salford University, UK.
}

\begin{abstract}
There has been an increasing interest from architects and urban planners regarding the influence of the local/traditional regulations particularly for land, property and user's rights issues. It is worth noting here that in Islamic countries, land, property and user's rights are ruled and protected according to permit forms controlled by specific religious contexts. In the Iraqi situation, the Islamic administration of user's rights in relation to land has itemized during the Ottoman period in the 15th century and finished in 20th century. The objective of this research is to produce a body of material, a closer look at the Ottoman law, which could enhance the real influences of this period on Iraqi administration. This article offers therefore basic opportunity to revisit elementary principles regarding Islam Ottoman period in Iraq. Prior work, however, has focused extensively on the historical and on certain aspects in recent systems of Iraqi law. This article showed that Iraqi current administration of land, property and user's rights is still influenced by regulations that were established during the Ottoman period. It concludes that the reform of Iraqi institutional framework can be held by socio-religious and political factors which potentially offer opportunities for the development of 'authentic' Islamic ownership tools that can support the campaign for the realization of fuller land rights for various sections of Muslim societies. Keywords: Iraq, Islamic-Ottoman reforms, land, tenure security, user's rights.
\end{abstract}

\section{INTRODUCTION}

The term 'Tenure' is a matter of awareness, which is associated with understanding to the level of rights and security [1, 2]. The United Nations Centre for Human Settlements (UNHABITAT) [3] report defines tenure as 'the way land is held or owned by individuals and groups, or the set of relationships legally or customarily defined amongst people with respect to land'. A useful summary of the land tenure is provided by the UN-HABITAT [4], which observed that it is an issue of varying elements created to manage land right within the registry titles within the institutional states. Furthermore, securing user's rights in land and property is a significant step to address the effective administration of end-user's rights by the state management institutions [5]. In practical terms, the literature shows that there is an interconnected matrix of legal, social and economic factors linked with the aspects of Land Tenure Security (LTS) administration.

Today, there is a growing agreement on the substantial contribution of LTS to achieving people rights and providing sustainable development [6-9]. Therefore, LTS should be arranged and protected in ways that the process of tool development should be taken into account. The Ottoman legislative categories under the religious form still apply to a large area in Muslim countries. Noticeably, across the Arab Mashreq region countries such as Iraq, Lebanon and Egypt, most property owners rely on the traditional system to regularize land titles. For example, the UN-HABITAT [9] has emphasized that Arab's Mashreq region settlers still depend on the Ottoman traditional (Hujja) system, as a practical common alternative under which they

This paper is part of the Proceedings of the International Conference on Islamic Heritage Architecture and Art (Islamic Heritage Architecture 2016)

www.witconferences.com 
can use it to gain rights to unused land through improvements. Also the main types of land tenure in the Arab Mashreq region can be divided into privately owned land (Mulk), community-owned cropland - mainly (Musha) with no written title - and finally state land [9]. However, this last category could be uncultivated land (Mawat) - used mainly for grazing under customary rights, but also for marginal cultivation with frequent fallow - mainly registered in the 20th century as state land or it could be Miri land [10]. Conspicuously, the UN-HABITAT [9] suggests that the Arab authorities still have significant misunderstanding about how to reform local land rights with modern categories, in order that they can improve own zoning regulations and the complexity of property bureaucratic procedures.

\subsection{User's rights in land and property}

Building on the categories of tenure rights that were listed by the World Resources Institute in collaboration with United Nations Development Programme [11], this article classifies user's rights in land and property into the following:

- The right to use the resource;

- The right to profit from use of the resource;

- The right to sell one's tenure rights to others, permanently or for a limited time;

- The right to pass down these rights to one's successors;

- The right to protection from illegal expropriation of the resource.

\section{QUESTIONS AND OBJECTIVES OF THE STUDY}

This article has been motivated by the continued impact of Islamic and traditional regulations in Iraqi society. Also, the article aims to identify the influence level of the current insecurity situation and the weakness of the government's role on the user's rights in land and property. From a theoretical background, this article developed and proposed its scope for the context of urban land development within Iraq. The following questions emerge as being essential to achieve the aim of the article:

1. What are the main Islamic and traditional factors affecting the efficiency of LTS?

2. How do these factors affect the current LTS in Iraq?

Based upon the associated literature, these questions can be achieved via the following objectives:

1. To develop an understanding of the Islamic and traditional systems and their classifications in Iraqi land tenure;

2. To explore the moderating effect of the LTS in Iraq identifying its current settings.

\section{OVERALL IRAQI HISTORY}

Located in the Middle East between the Euphrates and Tigris Rivers, Iraq became the centre of the ancient Babylonian and Assyrian empires as the Mesopotamia land. It was at one time the most significant commercial and cultural centre in the entire Muslim world. Iraq is an Arabic country with a population of 34 million [12, 13] (2014 est.). The country was pillaged by the conquerors in 12 th and during the 16th, 17th and 18th centuries. In 1638, for 
example, the Ottoman Turks conquered it. The Ottoman occupation of Iraq continued until 1917 when it was replaced by Britain [12]. During the British occupation of Iraq, the Mesopotamian region became known as the Sate of Iraq in 1920. In 1932, Iraq achieved full independence and became an independent kingdom with the British mandate authority $[14,15]$. According to Al Rashid [15], Iraq became fully independent from Great Britain in 1958, and has remained known as the Republic of Iraq. After US and British forces invaded the country in 2003, the dictatorship collapsed. Also many reports indicate that current social and political conflicts are important explanatory factors with potentially grave consequences. For example, the UN-HABITAT [3] declared that in Iraq as a result of conflicts, urban residents living in slum conditions rose from 2.9 million in 2000 to approximately 10.7 million in 2010 . Recently the chaos of looting and destruction of public records has also increased [3, 7, 8, 12, 14, 15]. Today, after more than a decade after the war, there is continued political and religious tension, semi-civil war and constant terrorist attacks. Moreover, the Iraqi refugee crisis still presents a national humanity problem. Due to these instable conditions, the Iraqi's future is unknown.

\subsection{Background of the Iraqi society}

In order to assess the development of the LTS and administration systems of user's rights in land and property in Iraq, in this article the Iraqi administration systems of LTS and user's rights will be classified according to the main forms of ownership based on social background and historical hierarchies.

\subsubsection{The Iraqi pastoral nomadic tribe's regulations of ownership}

Up until the end of the 19th century, as pastoral nomads, the tribes in the southern region of Iraq have influenced local frameworks for a ruling dynasty and tribal state. For example, Yitzhak [16] has shown that '...in 1867, 50 percent of the population in southern Iraq were nomads and 41 percent were cultivators, by 1905 this had changed to 19 and 72 percent, respectively'. However, that percentage was halved throughout the 20th century when the Iraqi urban dwellers increased their numbers much faster [17]. According to the vast influence of pastoral nomadic tribes in the southern regions of Iraq, Yitzhak [16] stated that these tribes were gradually forced to establish primitive settlements under the form of tribe unity. In the beginning the tribes were displaced pastoral nomads living a rural life and then they were organized within primitive neighbourhoods. The Al-Nasiriyah territory, for example, was established as a tribal city ruled by the clan dynasty of the sheikh $[14,15]$. Thus, land ended up registered in the name of the tribe sheikh, Naser Basha, and even the city took its name [16]. However, the tribal background was a working political alliance of clans based on social and religious conceptions. According to tribal rules, the tribal lands are private property and owned in the name of the tribal sheikh, who was thereby presenting his tribe's men [14]. In addition, the land ownership according to tribal rules is converted between men only [17] and that means the tribal lands are the ownership of tribe's members under the name of the sheikh. According to Sleglet and Peter [17] Iraqi land ownership under the rural and tribal background is a right of men. However, this influence has increased recently after 2003 and the fall of the state. According to the significant influence of pastoral nomadic tribes in the southern regions of Iraq, the land ownership according to the Iraqi tribal rules is passed between men only, which means the tribal lands are the ownership of tribe's members under the gender rules and namely in the name of the sheikh; and accordingly, land ownership under the tribal background is a right of men. Building on that discussion, the Iraqi pastoral 
nomadic tribe's regulations of ownership work as family relationship groups of clans based on social and religious conceptions. That can mean that land tenure rights are influenced by gender regulations according to tribal rules of ownership, since the land is registered in the name of the family men while women do not have that right. According to the article's focus area, Iraqi background of Tenure Administrations user rights in land and property can be classified within other legislative categories and according to forms of religious involvement in Islamic rules of ownerships, in which the following are included.

\subsubsection{Iraqi Islamic background of tenure administrations}

As an Islamic country, Iraqi land ownership is ruled and managed according to permit forms controlled by the specific religious authorities. The UN-HABITAT [9] has stated that within religious tenure systems, a number of tenure security categories exist. In a given authority, these include various types of shared ownerships. For example, Batatu [14], Al Rashid [15] and Mohammad [18]] have emphasized that in an Islamic land tenure system, there are four main categories included within the Islamic Shari'a (law): the first one is the 'Waqf' as land held for endowment; 'Mulk', or private ownership lands; 'Miri' the state-controlled land which carries 'Tassruf' or the government rights to use land; and the 'Musha', or communal lands. According to Sleglet and Peter [17] the modern Islamic land regulations in Iraq are renewed on the Ottoman code that can be provided for the existence of the following types of land tenure: (Mulk) Private land: right of full ownership and alienation, as well as right to the usufruct of the land; (Miri-Amirri) State land: the ultimate owner is the state but the usufruct belongs, in most cases, to individuals. The codification of Miri land in Ottoman era was often read as an attempt to centralize power against the large landlords and tribal groups by establishing individual rights for a large number of small individual cultivators. For example, Siraj and Lim [19] have define the following: (Waqf) endowed land: reserved and immobilized, for some public (e.g. charitable) purpose, and usually leased, as it was in the past; and (Mawat), so-called 'dead lands', unclaimed land: mainly used for grazing under common property regimes, and often a grey area with political undertones.

\section{THE OTTOMAN LAND OWNERSHIP REFORMS IN IRAQ}

This period started during the Ottoman occupation of Iraq in 1534 [18]. During the Ottoman period, most of the lands were owned in a feudal system, by the powerful families of tribal lords [2, 13-16, 18]. In Iraq, according to Siraj and Lim [19], land was held by socio-economic and political factors which combined to inhibit the development of individual landholding. In fact, the land was held by the tribal landowners, many of whom were tribal sheikhs. In practice, land tenure was classified into several categories with legal sources of transfer [15]. For example, TAPU (Ottoman's form of land ownership title deeds) was the legal source that provided individual rights while most of the land ownership was owned by legal sources of ownership title deeds. However, further TAPU grants were banned after 1881, and the Ottomans made numerous attempts over the next thirty years to repossess the lands [17]. Thus, during the next era of the British occupation in 1914 some $80 \%$ of the land was Miri and a small fraction was TAPU [19]. In practice, Iraqi land administration was established during the Ottoman period. The main land reform within this period can be identified into land owned by the state and public land use, land held individually and finally land held by religious rules. Although secular legal institutions have held power in modern Iraq, the religious law still functioned to a large area of legal institutions in civil laws. For example, land laws and regulations are rooted and still depend on the Ottoman legal codes in the civil code rather than the modern laws [19]. According to Siraj and Lim [19] '...The only civil code in existence was the Mejelle, which 
was a code of civil contracts rather than a complete civil code in the modern sense.' In addition to the Mejelle, there existed the Ottoman Land Code, the Tapu law, the law of disposition of immovable property, the law of succession to immovable property and many other civil code rules scattered throughout the Code of Civil Procedure and the Land Commercial Code and the Peace Judges' Law $[19,20]$. In this sense, the religious law still applied to a large area of civil transactions, such as inheritance, succession, wills, marriage and divorce, and the administration of pious foundations (Waql) [20]. In brief outline of Iraq's legal roots, within this period, the Iraqi land tenure system was slightly changed while most of the land regulations were still influenced by the old policy of feudalism and tribalism (Table 1).

Table 1: The Ottoman main land ownership regulations in Iraq (Author).

\begin{tabular}{lll}
\hline Land type & System name & Regulations \\
\hline $\begin{array}{l}\text { - Privately } \\
\text { held land }\end{array}$ & $\begin{array}{l}\text { Rights gained through TAPU } \\
\text { authorization/allocation }\end{array}$ & $\begin{array}{l}\text { Ottoman land rights law; Declaration } \\
\text { No. 24 (given 1910) [20] }\end{array}$ \\
- Owned by & Ameriya (Miri) lands (State & Ottoman Land Rights law; Declaration \\
$\begin{array}{l}\text { Ottoman } \\
\text { State }\end{array}$ & land) & No. 15 (given 31 December 1918). Item \\
& & $\begin{array}{l}\text { 10 Land Rights Law (Ottoman land } \\
\text { system established about 1890) [20] }\end{array}$ \\
- Endowed & Waqf & Ottoman land rights law \\
lands & & \\
- Public land & Mewat & Ottoman land rights law \\
\hline
\end{tabular}

\subsection{The Ottoman legislative category terms in Iraq}

In the 20th century, Iraq blended many elements of the continental civil law tradition with the enactment of its modern civil code into its legal culture [5, 19]. As late as the early 20th century, Iraqi land laws were largely comprised of numerous Ottoman legal codes, and terms used for land tenure in Iraq were translated to Arabic, as are listed in Table 2.

Table 2: Arabic land tenure terms used in Iraq (Author).

\begin{tabular}{|c|c|c|}
\hline System & Terms & Definition \\
\hline \multirow[t]{8}{*}{1 - Registry codes } & - Amirry/Miri & State land \\
\hline & - Amlak adawla & Government land \\
\hline & - Tamalok & Rights of possession \\
\hline & - Hakem (Wali) & District governor \\
\hline & - Hukm & Order, appointment to act \\
\hline & - Hoquq & Law, rights \\
\hline & - Imlak & Registry office/Registered land/property \\
\hline & - Hudood & Land territory \\
\hline
\end{tabular}


Table 2: (Continued).

\begin{tabular}{|c|c|c|}
\hline System & Terms & Definition \\
\hline & - Qazi & Judge \\
\hline & - Qanoon law & Code of regulations \\
\hline & - Qanoon madani & Civil Code \\
\hline & - Wakil & Lawyer, representative \\
\hline & - Wali & District governor \\
\hline & - Wakaalat & Acting on another's behalf \\
\hline & - Sanad & Document (generic) \\
\hline & - TAPU & $\begin{array}{l}\text { Rights gained through Code of } \\
\text { regulations }\end{array}$ \\
\hline \multirow[t]{7}{*}{2 - Religious codes } & - Shar'ia & The Islam law \\
\hline & - Shura, majlis & Council, committee \\
\hline & - Urfee & Traditional agreement/sale \\
\hline & $\begin{array}{l}\text { - Waqf (see also } \\
\text { Moquofa) }\end{array}$ & $\begin{array}{l}\text { Common land, usually used for religious } \\
\text { purposes (Mosques, Shrines) }\end{array}$ \\
\hline & - Meerath & Inheritance form \\
\hline & $\begin{array}{l}\text { - Maoqofa (see also } \\
\text { Waqf) }\end{array}$ & $\begin{array}{l}\text { Common land often used for religious } \\
\text { purposes }\end{array}$ \\
\hline & - Nodhoum & Regulations \\
\hline \multirow[t]{7}{*}{3 - Land forms } & - Arasaa & Land \\
\hline & - Baayer & Virgin land, wasteland \\
\hline & - Ijara & Rented land/house \\
\hline & - Mushtarak & Shared land \\
\hline & - Manteqa & Local area, territory \\
\hline & - Iqtaei & Feudal landlord \\
\hline & - Mawaat & Barren land or wasteland \\
\hline 4 - Private ownership & - Malek, (Mulk) & Land owner(s) \\
\hline
\end{tabular}

4.2 The Ottoman basic land tenure practices in Iraq

Aside from the underlying Islamic influence, the promulgation of the Ottoman land code was a remarkable and vital development in the empire's administration [19, 20]. And these figures need to be approached with caution; its application suffered from corruption, bureaucracy and centralization. For example, the Ottoman land laws have been inherited by modern Jordanian land laws. For example, Jordan issued Civil Law No. 43/1976, which in its content and approach clearly superseded the Ottoman Mejelle of 1869 [21]. In practice, from Ottoman land rights, an overall Iraqi basic land tenure categories and practices influencing the administration of land tenure and end-user's rights are illustrated in Table 3. 
Table 3: Overall Iraqi basic land tenure categories and practices (Author).

\begin{tabular}{|c|c|c|c|}
\hline Land type & Contributing & Practices & Legal source \\
\hline Ameriya (Miri) & $\begin{array}{l}\text { - State land, owned by } \\
\text { governorate }\end{array}$ & $\begin{array}{l}\text { - The Ottoman era } \\
\text { and still exists } \\
\text { under state } \\
\text { regulations }\end{array}$ & $\begin{array}{l}\text { - Ottoman land } \\
\text { rights. } \\
\text { - State regulations of } \\
\text { ownership }\end{array}$ \\
\hline Mulk & $\begin{array}{l}\text { Rights gained } \\
\text { through TAPU title, } \\
\text { allowing various } \\
\text { degrees of freedom } \\
\text { in the use of the } \\
\text { property }\end{array}$ & $\begin{array}{l}\text { - Private ownership } \\
\text { and governed by } \\
\text { land rights laws, } \\
\text { still exists }\end{array}$ & $\begin{array}{l}\text { - Ottoman land } \\
\text { rights } \\
\text { - State regulations of } \\
\text { ownership }\end{array}$ \\
\hline Waqf & $\begin{array}{l}\text { Mainly religious } \\
\text { endowments, trans- } \\
\text { lation of private } \\
\text { ownership within an } \\
\text { endowed land gov- } \\
\text { erned and regulated } \\
\text { by Islamic law }\end{array}$ & $\begin{array}{l}\text { - The Ottoman era, } \\
\text { still exists }\end{array}$ & $\begin{array}{l}\text { - Ottoman land } \\
\text { rights } \\
\text { - The British } \\
\text { Mandate land } \\
\text { rights } \\
\text { - The recent State } \\
\text { regulations laws }\end{array}$ \\
\hline Empty land & $\begin{array}{l}\text { - The dead land } \\
\text { (Mewat) is unde- } \\
\text { veloped land at a } \\
\text { distance from any } \\
\text { town or village }\end{array}$ & - The Ottoman era & $\begin{array}{l}\text { - Ottoman land rights } \\
\text { - The British Man- } \\
\text { date land rights } \\
\text { - The recent State } \\
\text { regulations laws }\end{array}$ \\
\hline \multirow[t]{2}{*}{$\begin{array}{l}\text { Land rights use } \\
\text { for a fixed term }\end{array}$} & $\begin{array}{l}\text { - Rights of use and } \\
\text { benefit land }\end{array}$ & $\begin{array}{l}\text { - The Ottoman era, } \\
\text { still exists }\end{array}$ & \\
\hline & $\begin{array}{l}\text { Rights of use and } \\
\text { benefit for a fixed } \\
\text { term of years dur- } \\
\text { ing which the land } \\
\text { and property is still } \\
\text { owned to grantor }\end{array}$ & $\begin{array}{l}\text { - The Ottoman era, } \\
\text { still exists }\end{array}$ & $\begin{array}{l}\text { - Ottoman land } \\
\text { rights } \\
\text { - State regulations of } \\
\text { ownership }\end{array}$ \\
\hline Communal lands & $\begin{array}{l}\text { The term was used } \\
\text { at village level to } \\
\text { denote either } \\
\text { common undivided } \\
\text { land or communal } \\
\text { grazing land }\end{array}$ & $\begin{array}{l}\text { - The Ottoman era, } \\
\text { still exists }\end{array}$ & $\begin{array}{l}\text { - State regulations of } \\
\text { ownership laws: } \\
\text { - Civic Code Art } 68 \\
\text { (1958) } \\
\text { - Civic Code Bk. } 1 \\
\text { (1929) }\end{array}$ \\
\hline Cultivated land & $\begin{array}{l}\text { - Communal grazing } \\
\text { land rights }\end{array}$ & $\begin{array}{l}\text { - Still exists under } \\
\text { the new state } \\
\text { regulations }\end{array}$ & $\begin{array}{l}\text { - Ottoman land rights } \\
\text { - Pastoral lands, as } \\
\text { opposed to culti- } \\
\text { vated land }\end{array}$ \\
\hline
\end{tabular}


Table 3: (Continued).

\begin{tabular}{llll}
\hline Land type & Contributing & Practices & Legal source \\
\hline Tenancies & $\begin{array}{l}\text { Rights of use and } \\
\text { benefit for specific } \\
\text { amount and period }\end{array}$ & $\begin{array}{l}\text { - Still exists under } \\
\text { the state renting } \\
\text { regulations }\end{array}$ & $\begin{array}{l}\text { - Ottoman land rights } \\
\text { - State regulations of } \\
\text { ownership such as: } \\
\text { Lell-buy process }\end{array}$ \\
& $\begin{array}{l}\text { Long complex trans- } \\
\text { action procedures that } \\
\text { takes place at the Real }\end{array}$ & $\begin{array}{l}\text { Still exists under } \\
\text { the state renting } \\
\text { regulations } \\
\text { Estate Registration } \\
\text { Department (RERD) }\end{array}$ & $\begin{array}{l}\text { Issuing the title } \\
\text { deed to be exam- } \\
\text { ined accurately at } \\
\text { the RERD }\end{array}$ \\
\hline
\end{tabular}

Table 3 shows a brief outline of Iraq's legal roots of administration of land tenure and enduser's rights required for any complete discussion of Iraqi law. Aside from the underlying Islamic influence, the Iraqi legitimate characteristics of land tenure established its own land laws based essentially on local situation and social-religious regulations of ownership in specific arrangements and administrations and across the different periods.

\section{SUMMARY AND CONCLUSIONS}

In this article, the evaluation criteria for land, property and user's rights in Iraq were identified according to the Islamic rules of ownership. Basic information as well as an opportunity to revisit basic principles regarding Islam Ottoman period in Iraq are achieved. This article showed that Iraqi administration has a long and rich legal history that included complex, secular legal regimes and applications of religious rules. Attention was given to investigate the socio-religious and legal factors and connecting them with Iraqi current situation as the main influencing factors during the contemporary period. The general finding of the article showed that Iraqi current administration of land, property and user's rights is still influenced by regulations that were established during the Ottoman period. The article therefore can draw lessons regarding Islam Ottoman period in Iraq in the following key areas: tenure security; land management and administration; protecting the user's rights in land and property. Nevertheless, the conclusion identifies some emerging issues requiring particular attention from policy makers and development agencies of tenure and property rights. Consequently, Iraqi administration collaborating at different institutional levels of user's rights can help to fill the current gap. However, quantitative researches and field surveys may suggest otherwise; primary data will be of benefit to confirm some of these requirements by using the tools of interview and the questionnaire data collection for further efficiency of these aspects.

\section{REFERENCES}

[1] Payne, G. \& Durand-Lasserve, A., Holding on: security of tenure - types, policies, practices and challenges. The Raquel Rolnik, Study on Security of Tenure, pp. 22-23, 2012.

[2] USAID, Land Registration and Property Rights in Iraq, Iraqi Local Governance Program. RTI International/Research Triangle Park, NC 27709-2194. EDG-C-00-03-00010-00, January 2005.

[3] United Nations Centre for Human Settlements (UN-HABITAT), Land Registration and Property Rights in Iraq, Iraqi Local Governance Program. RTI International/Research Triangle Park, NC 27709-2194. EDG-C-00-03-00010-00, January 2005. 
[4] United Nations Centre for Human Settlements (UN-HABITAT), Handbook on best practices, security of tenure and access to land, implementation of the habitat agenda. Land and Tenure Section, Shelter Branch Shelter and Sustainable Human Settlement Development Division, Nairobi. HS/588/99E, ISBN 92-1-131446-1, 2003.

[5] Abdul Rauf, F. (ed.), Defining Islamic Statehood: Measuring and Indexing Contemporary Muslim States, Palgrave Macmillan: Basingstoke, UK, ISBN1137446838, 9781137446831, 2015.

[6] Rakodi, C. \& Leduka, C., Informal Land Delivery Processes and Access to Land for the Poor: A Comparative Study of Six African Cities, University of Birmingham: Birmingham, Policy Brief 6, 2004.

[7] Michael, H. \& Nika, K., Attaining social order in Iraq. Paper presented at the Conference on Order, Conflict and Violence at Yale University, New Haven, Connecticut, 30 April-1 May 2004.

[8] Roberto, T., El-Hakim, A., Aden-Aw, H., Boubaker, D., Hatem, S. \& Fadil, R., Agricultural policies and institutions in Iraq - a historical perspective. The International Centre for Agricultural Research (ICARDA), AusAID and the Italian Government, Iraq Salinity Project Technical Report 9, 2012.

[9] United Nations Centre for Human Settlements (UN-HABITAT), Security of Tenure Best Practices, p. 8, 2013.

[10] Majid, K., Socialist Iraq: A Study in Iraqi Politics since 1968, The Middle East Institute: Washington, DC, p. 117, 1978.

[11] World Resources Institute in collaboration with United Nations Development Programme, United Nations Environment Programme and World Bank, The Wealth of the Poor - Managing Ecosystems to Fight Poverty. WRI: Washington, DC, 2005.

[12] Infoplease, Iraq, available at http://www.infoplease.com/country/iraq.html?pageno=2, 2015, (C) 2000-2016 Sandbox Networks, Inc.

[13] Iraqi Ministry of Housing \& Construction, Iraq, available at http://imariskan.gov.iq/ index.php?q=node $/ 4$.

[14] Batatu, H., The Old Social Classes and the Revolutionary Movements of Iraq: A Study of Iraq's Old Landed and Commercial Classes and of its Communists, Ba 'thists and Free Officers, Princeton University Press: Saqi Books, NJ, 2004. ISBN978-0-86356-520-5.

[15] Al Rashid, Y., The role of the Baathist state in the land reforms and co-operative development in Iraq's agriculture 1958-1970. Lessons for those attempting political and economic reform in the emerging Iraq. International Journal of Co-operative Management, IJCM, 2(1), pp. 9-20, 2005.

[16] Yitzhak, N., The conversion of Iraq's tribes to Shiism. International Journal of Middle East Studies, 26(3) , pp. 443-463, 1994.

[17] Sleglet, F. \& Peter, S., Changes in land-ownership and social structure in middle and southern Iraq for the period 1858-1870. International Middle East Journal, 15, pp. 491-505, 1983.

[18] Mohammad, F., Islamic Law and Civil Code: the law of property in Egypt. Journal of Islamic Studies, 24(1), pp. 94-97, 2013. DOI: 10.1093/jis/ets070.

[19] Siraj, S. \& Lim, H., Land Law, and Islam: Property and Human Rights in the Muslim World. Civil Liberties \& Political Activism, ISBN-10: 1842778137, ISBN-13: 9781842778135, Zed Books: London, pp. 23-24, 2006.

[20] Stigall, E., A closer look at Iraqi property and tort law. HeinOnline, William S. Hein \& Co., Inc. \& HeinOnline (http://heinonline.org) Louisiana Law Review, 68, pp. 176-177, 2008.

[21] Al-Sanhfr, A., Reconstruction of the Islamic law of contract defects. Journal of Islamic Studies, 6 (Al-qanon Almadant, No. 40 (1951)), pp. 153-167, 1995. 